\title{
THE CONTRIBUTION OF ENERGY EFFICIENCY TOWARDS THE SUCCESS OF INDUSTRIAL ORGANISATIONS IN SOUTH AFRICA
}

\author{
P.A. Gouws ${ }^{1}$, A.C. Brent ${ }^{2 *} \&$ W.T. Pierce ${ }^{3}$ \\ ${ }^{1,2}$ Graduate School of Technology Management \\ University of Pretoria, South Africa \\ 2alan.brent@up.ac.za \\ ${ }^{2,3}$ Centre for Renewable and Sustainable Energy Studies \\ Stellenbosch University, South Africa
}

\begin{abstract}
Internationally, governments and lobby groups increasingly put pressure on organisations to reduce their impact on the environment. To this end, various studies show the drivers, barriers, and contributions of energy efficiency towards a more sustainable environment, particularly through reduced greenhouse gas emissions and other by-products. In the study summarised in this paper, the factors that drive organisational success were compared with the effects that energy efficiency projects have on organisations. Methods, policies, and strategies on the application of energy efficiency were also studied. The findings are that, in general, most organisations have energy efficiency policies and strategies in place, and they include internal and external stakeholders in their energy efficiency efforts. These efforts also show a positive correlation with the factors that contribute to the perceived success of organisations in the South African industrial sector. These strategies must be maintained in the longer term, as energy efficiency will play a more important role in the future.
\end{abstract}

\section{OPSOMMING}

Organisasies, wêreldwyd, word toenemend onder druk geplaas deur regerings- en aksiegroepe om hul impak op die omgewing te verminder. $\mathrm{Na}$ aanleiding hiervan toon verskeie studies die drywers, struikelblokke en bydraes van energie-doeltreffendheid na 'n meer volhoubare omgewing, veral ten opsigte van groenhuisgas-emissies en ander neweprodukte. In hierdie studie is die faktore wat die sukses van organisasies dryf vergelyk met die effek van die toepassing van energiedoeltreffendheidsprojekte op organisasies. Metodes, beleid en strategieë in terme van die toepassing van energiedoeltreffendheid is ook bestudeer. Die bevindinge is dat die meeste organisasies, oor die algemeen, beleid en strategieë in plek het in terme van energiedoeltreffendheid; dié organisasies sluit interne en eksterne belanghebbendes in waar hulle strewe na energiedoeltreffendheid. Hierdie aktiwiteite toon 'n positiewe korrelasie met die faktore wat waarde bydra ten opsigte van die oënskynlike sukses van organisasies in die Suid-Afrikaanse industriële sektor. Dus moet hierdie strategieë in plek gehou word in die langtermyn, aangesien energiedoeltreffendheid ' $n$ belangriker rol sal speel in die toekoms.

\footnotetext{
${ }^{1}$ The author was enrolled for an M Eng (Technology Management) in the Graduate School of Technology Management, University of Pretoria.

* Corresponding author
} 


\section{INTRODUCTION}

The pressure to adopt more energy efficient technologies is increasing globally. Energy efficiency is one of the reasons for emissions reduction, and combating the cost of energy has become vital for organisations engaged in international trade [1]: they need to comply with energy efficiency efforts and programmes.

Galitsky et al. [2] found that $37 \%$ of the energy consumed globally is in the industrial sector. So the industrial sector has a considerable influence on the energy use profiles of countries; and the costs of energy, in turn, have a substantial effect on the financial performance of industrial organisations. But becoming more energy efficient normally comes at a cost, and so there must be some form of incentive for organisations. These incentives can be translated into factors that should contribute to business success. In the study summarised in this paper, the role that energy efficiency might play in the future of organisations, and what the drivers are for the efficient use of energy in the South African industrial sector, were explored.

\section{ENERGY EFFICIENCY AND THE PERFORMANCE OF ORGANISATIONS}

Five facets contribute to the performance and success of an organisation. Adams \& Neely [3] describe the five facets as a 'prism' consisting of stakeholder satisfaction, strategies, processes, capabilities, and stakeholder contribution. It is clear that the performance prism is not based on only the financial performance of an organisation, and that financial performance is a secondary outcome of the five facets of the performance prism. Energy efficiency is also not a direct component of the performance prism, but one that could influence its facets indirectly. Today most stakeholders and business associates require organisations to be compliant with environmental regulations, and to have international certification such as ISO 14001 for environmental performance. The latter requires organisations [1] to:

- develop an environmental policy;

- identify the firm's activities, products, and services that interact with the environment;

- $\quad$ identify legislative/regulatory requirements;

- identify the firm's priorities and set objectives and targets for reducing its environmental impacts;

- $\quad$ adjust the firm's organisational structure to meet those objectives, such as assigning responsibility, training, communicating, and documenting; and

- $\quad$ check and correct the environmental management system.

The environmental performance of organisations can be measured by studying physical indicators of materials and energy inputs and outputs from the production process, business or management indicators linking physical aspects of environmental performance with economic implications, and indicators that relate to emissions or potential environmental impacts. These indicators, similar to financial ration analysis, can be used to compare different industries or to benchmark the environmental performance of organisations in similar industries [1].

\subsection{Barriers to energy efficiency project implementation}

The cost of implementing energy efficiency may be such that it does not present a good business case in the short term, and that the payback from such projects is insufficient for organisations. Other barriers to energy efficiency are classified as follows:

- $\quad$ Energy consumers, who range between those who cannot afford energy efficiency and those who are simply ignorant about energy efficiency and its impact on the environment;

- $\quad$ End user equipment that is bought more with the initial acquisition cost in mind, totally ignoring its energy efficiency and environmental effects; 
- $\quad$ Producers and distributors of energy carriers, who are supposed to earn revenue from the sale of energy, so that energy saving is against their basic operational objectives;

- Actual and potential co-generators are usually in competition with one another, and sometimes the efficient generation of energy is not the most cost-effective solution when competing;

- National financial institutions have policies to concentrate on the financial aspects of projects and organisations; those with the best financial results, payback, and return on investment are preferred above energy efficient ones that sometimes have a higher acquisition cost; and

- Governments or countries that do not have policies and regulations in place to promote energy efficiency.

The barriers are not easily overcome, and a measure to deal with one barrier will not necessarily overcome all of them. Painuly et al. [4] prescribe the following actions to remove the financial barriers to energy efficiency:

- $\quad$ Create a market for energy efficiency projects. Initially government support would be needed to include the opening of government facilities for energy service company $(\mathrm{ESCO})^{2}$ projects so that demonstration projects are made available to the market. Government can also act by setting up energy efficiency standards, so that organisations can benchmark themselves or their processes to an energy efficiency standard.

- $\quad$ Develop a local financing market that will unlock financing for energy efficiency projects. Specialised energy efficiency banking will need to be developed in commercial banks, and their personnel will need to be trained to understand the methodologies and technologies that contribute to energy efficiency. Energy efficiency funds that are supported by governments, multilateral agencies, and donors in this area could also be needed. This form of finance could then be used by projects that have longer paybacks. A guarantee fund will have to be created, as banks and other institutions will require guarantees on the reduction of energy consumption of a project financed by them.

- $\quad$ Develop energy services companies (ESCOs) and energy efficiency institutions, as they will promote energy efficiency and offer customers the necessary support for monitoring, verification, reporting, and design. Databases of model contracts and procedures need to be available for ESCOs so that they have the tools to support them. Government involvement might be needed to help in the development of ESCOs.

Current theories and models in the literature thus show that energy efficiency projects need to have barriers removed, and that the support of governments and other institutions needs to be applied economically and effectively.

\subsection{Objectives of this paper}

Energy efficiency contributes both directly and indirectly to business success factors. As energy prices and the pressure of environmental issues increase, energy efficiency will be increasingly important. As part of business strategy, and of government and business policies, it apparently contributes to the long-term sustainability of organisations and society through reducing operating costs and adverse impacts on the environment. The objectives of this paper, then, are to investigate the effects of energy efficiency on organisations, how it is managed, and the extent to which it contributes to organisational success. 


\section{CONCEPTUAL FRAMEWORK OF ENERGY EFFICIENCY AND ITS RELATIONSHIP WITH DIFFERENT ASPECTS OF AN ORGANISATION}

Figure 1 shows the conceptual framework of organisational success that is linked to energy efficiency, and the relationship between the aspects as suggested in the literature. Direct and indirect energy ${ }^{3}$ are inputs into the processes in the organisation, which are managed by organisational strategies, policies, and management practices.

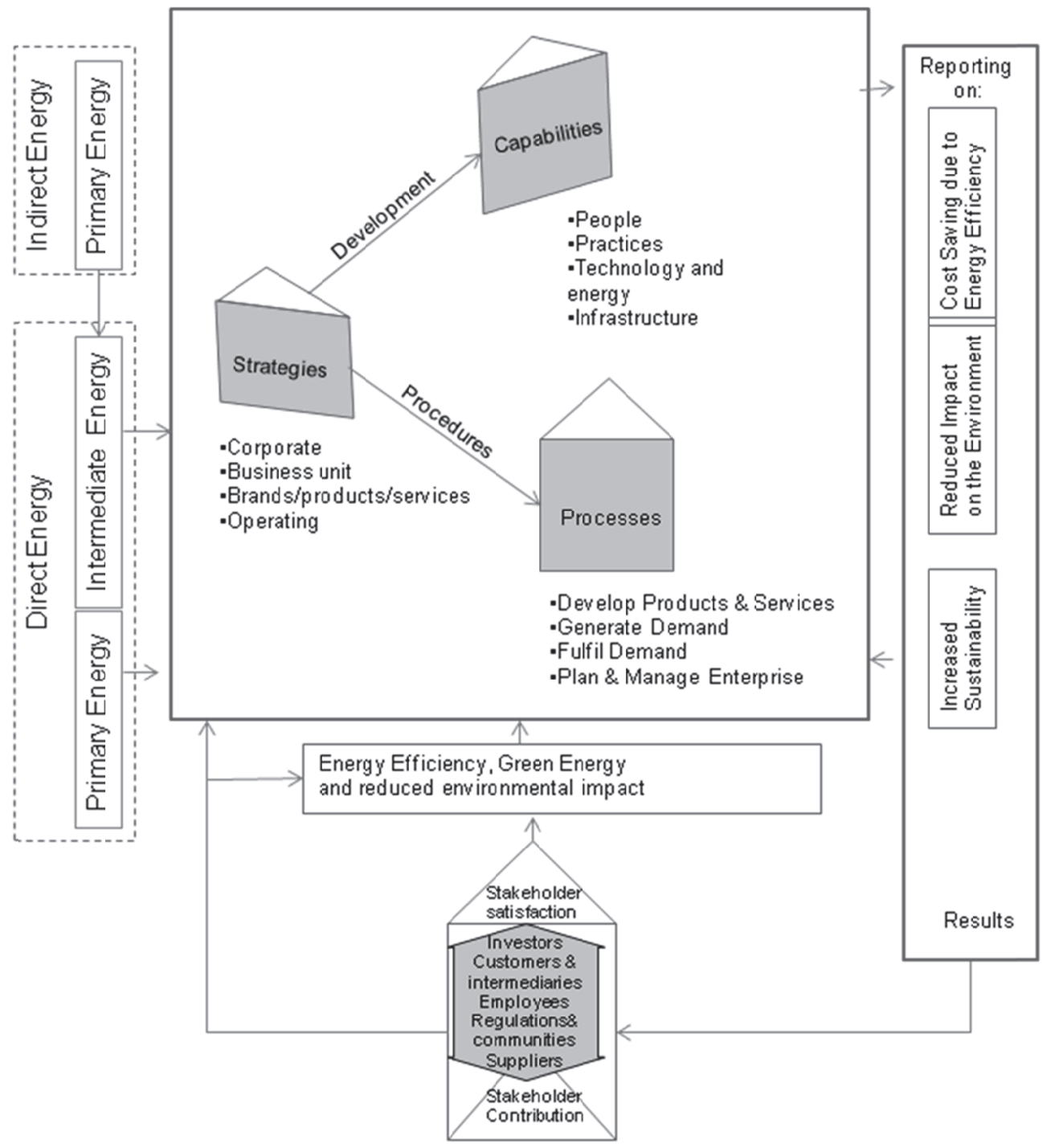

Figure 1: Conceptual framework of energy efficiency and business success

Energy service companies (ESCOs), consultants, or internal energy management specialists could recognise opportunities to use energy in the processes and organisation more efficiently, or to use greener energy resources.

3 Direct energy is consumed directly from an energy carrier such as electricity or fuel, while indirect energy is embodied in goods or services. 
Better energy efficiency will contribute to reduced energy costs in the organisation, fewer emissions (with associated benefits such lower penalties and less exposure to future carbon taxes), better environmental performance, and a higher level of sustainability because of all the energy efficiency improvements [5]. The resultant savings on energy and the reduced environmental impact, through the application of energy efficiency, can be compiled into a report and shared with the organisation's stakeholders and potential investors. The suggestion is that this will encourage investment, as shareholders and stakeholders are inclined to support sustainable, energy-efficient, and environmentconscious organisations [6]. The support from stakeholders can help to produce more investment in energy efficiency in the organisation, forming a continuous process of improvement in energy efficiency and environmental performance [7].

\section{RESEARCH METHODOLOGY}

To determine whether the conceptual framework is representative of South African organisations, the exploratory study tested the proposition that energy efficiency will influence the success of an organisation. A questionnaire was sent to companies in the industrial sector, based on a stratified random selected sample from different areas in South Africa. The only anticipated problem with the approach was to obtain a statistically significant sample. To ensure both a stratified and a statistically significant sample, the survey was sent to more than 300 selected organisations. The selection was based on organisation size, industrial activity, and geographical location. A small percentage of the organisations that were approached - 34 out of the $300(\approx 11 \%)$ - responded. Table 1 shows the number of respondents, classified by industrial background or activity.

\begin{tabular}{|l|c|c|}
\hline \multicolumn{1}{|c|}{ Industrial background / activity } & Number of respondents & \% of Total \\
\hline Automotive components & 2 & $6 \%$ \\
\hline Chemical manufacturers & 2 & $6 \%$ \\
\hline Construction materials and/or services & 3 & $9 \%$ \\
\hline Food and beverage & 3 & $9 \%$ \\
\hline Manufacturing & 4 & $12 \%$ \\
\hline Mining supplies & 1 & $3 \%$ \\
\hline Other & 7 & $21 \%$ \\
\hline Packaging material / paper manufacturer & 4 & $12 \%$ \\
\hline Service providers & 5 & $15 \%$ \\
\hline Metal industry & 3 & $9 \%$ \\
\hline Total & 34 & $100 \%$ \\
\hline
\end{tabular}

a. This included textiles, wood products, machinery, and other transportation equipment.

Table 1: Characteristics of the respondents of the survey

Organisations that chose to respond might be more active in the area of energy efficiency, and therefore the analysis might include a bias that could not be avoided. However, from interactions with the organisations that were approached, the main reason for not participating was, apparently, the time and resources required, not their attitude towards energy efficiency.

It was expected that organisations of different sizes might have different approaches to and reasons for applying energy efficiency projects; and this needed to be considered during the study. The type of industrial activity, such as food and beverage, automotive components, engineering works, metal processing plants, and assembly lines, will be influenced differently by energy efficiency; but they could also experience different opportunities, costs, and savings by applying energy efficiency projects.

The geographical location could also play a role in the application and results of energy efficiency projects. Organisations located within metropolitan areas will have more 
exposure to energy efficiency and green energy specialists, products, and services than those in remoter locations.

The data was processed using the method described in Figure 2 [8]. The investigation was then focused on how reporting on energy efficiency and on its effects on the environment might increase the possibility of an organisation's success [9].

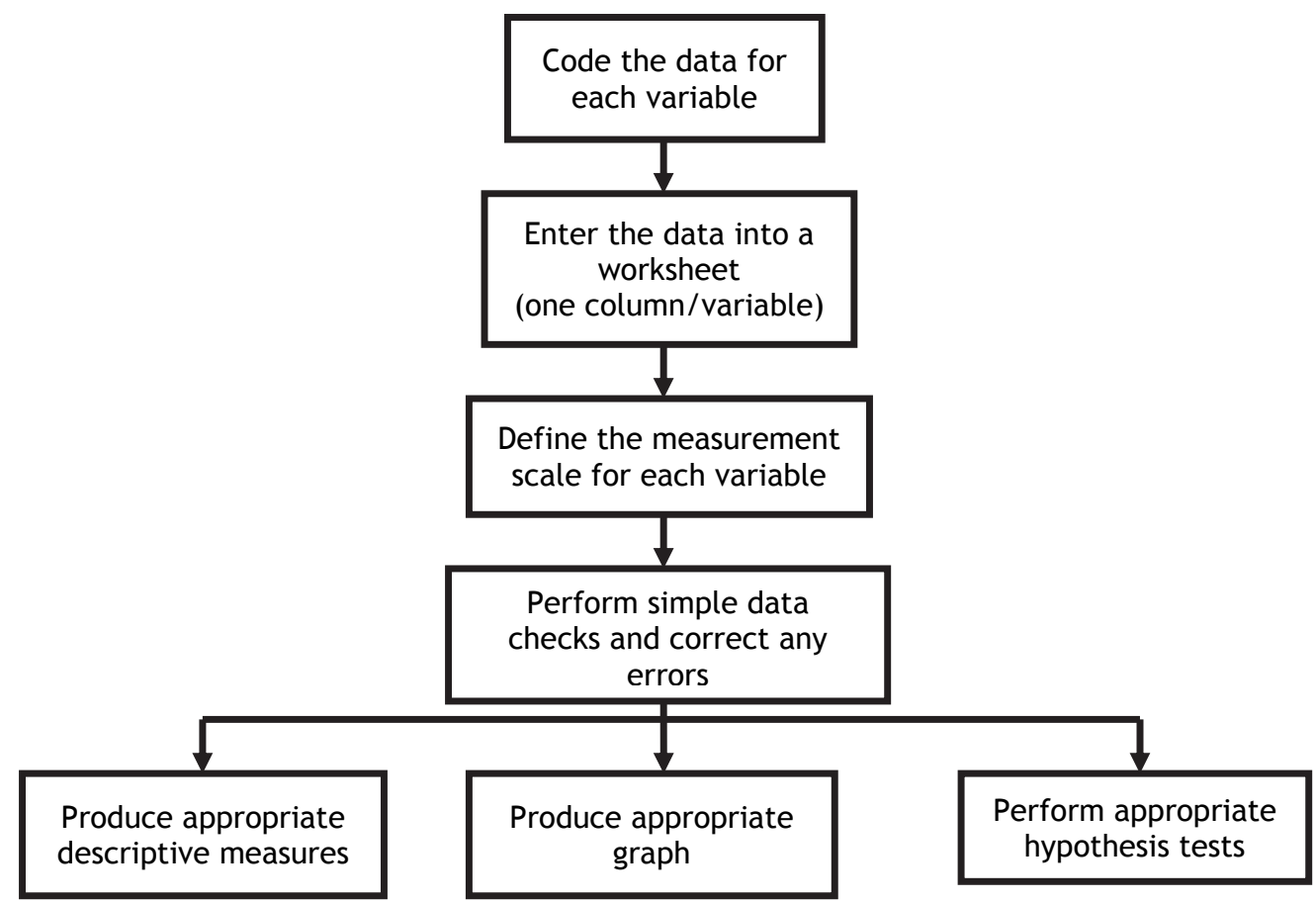

Figure 2: Data analysis process

\section{RESULTS}

Fourteen correlations could be studied from the questionnaire that compared variables of organisational success with variables of energy efficiency [9]. The correlations that were found between responses indicating a relationship between organisational growth and the application of energy efficiency are listed in Table 2. Other important correlations are given in Table 3. The confidence level of the data used to calculate the correlation coefficients in the tables, calculated from the sample size, is $83 \%$. In general the results indicate that there is a positive correlation between variables that contribute to energy efficiency and variables that determine organisational success.

\subsection{Drivers for energy efficiency}

The most important driver for energy efficiency - and one that also contributes to organisational success - is organisational and financial growth. Another factor that indirectly contributes to organisational success is environmental sustainability. Organisations that want to trade with other environmentally-certified (ISO) organisations will be required to have some form of environmental control measures in place. 


\begin{tabular}{|l|l|c|}
\hline \multicolumn{1}{|c|}{$\begin{array}{c}\text { Factors relating to } \\
\text { energy efficiency }\end{array}$} & \multicolumn{1}{|c|}{$\begin{array}{c}\text { Factors relating to } \\
\text { organisational growth }\end{array}$} & $\begin{array}{c}\text { Correlation } \\
\text { Coefficient }\end{array}$ \\
\hline $\begin{array}{l}\text { Energy efficiency will earn organisations } \\
\text { a licence to trade in some markets }\end{array}$ & $\begin{array}{l}\text { Compliance with (future) } \\
\text { regulations or national } \\
\text { policies/strategies }\end{array}$ & 0.57 \\
\hline $\begin{array}{l}\text { More energy-efficient products are } \\
\text { offered to our customers }\end{array}$ & $\begin{array}{l}\text { Expected annual growth of the } \\
\text { organisation }\end{array}$ & 0.55 \\
\hline $\begin{array}{l}\text { Organisations that have procedures and } \\
\text { policies in place for energy efficiency } \\
\text { and green energy usage }\end{array}$ & $\begin{array}{l}\text { Expected annual growth of the } \\
\text { organisation }\end{array}$ & 0.50 \\
\hline $\begin{array}{l}\text { Percentage reduction in energy usage } \\
\text { by applying energy efficiency }\end{array}$ & $\begin{array}{l}\text { Expected annual growth of the } \\
\text { organisation }\end{array}$ & 0.37 \\
\hline $\begin{array}{l}\text { The importance of promoting a } \\
\text { sustainable environment through energy } \\
\text { efficiency }\end{array}$ & $\begin{array}{l}\text { Compliance with (future) } \\
\text { regulations or national } \\
\text { policies/strategies }\end{array}$ & 0.12 \\
\hline $\begin{array}{l}\text { Energy efficiency will play a role in the } \\
\text { profitability of the organisation }\end{array}$ & $\begin{array}{l}\text { Financial return is an important } \\
\text { driver for organisational growth }\end{array}$ & -0.15 \\
\hline $\begin{array}{l}\text { Energy efficiency will promote } \\
\text { compliance with (future) regulations or } \\
\text { national policies/ strategies }\end{array}$ & $\begin{array}{l}\text { Expected annual growth of the } \\
\text { organisation }\end{array}$ & \\
\hline
\end{tabular}

Table 2: Correlation between energy efficiency and organisational growth

\begin{tabular}{|l|l|c|}
\hline \multicolumn{1}{|c|}{ Variable 1 } & \multicolumn{1}{|c|}{ Variable 2 } & $\begin{array}{c}\text { Correlation } \\
\text { Coefficient }\end{array}$ \\
\hline $\begin{array}{l}\text { Measurements of productivity in the } \\
\text { organisation include measurements of } \\
\text { efficient use of energy }\end{array}$ & $\begin{array}{l}\text { Overall success of the } \\
\text { organisation (it is important for } \\
\text { survival) }\end{array}$ & 0.53 \\
\hline $\begin{array}{l}\text { Organisations that have procedures and } \\
\text { policies in place for energy efficiency } \\
\text { and green energy usage }\end{array}$ & $\begin{array}{l}\text { Internationally-owned } \\
\text { organisations }\end{array}$ & 0.43 \\
\hline $\begin{array}{l}\text { Energy efficiency will help to promote a } \\
\text { sustainable environment }\end{array}$ & $\begin{array}{l}\text { Internationally-owned } \\
\text { organisations }\end{array}$ & 0.43 \\
\hline $\begin{array}{l}\text { Overall success of the organisation (it } \\
\text { will be important for survival) }\end{array}$ & $\begin{array}{l}\text { Organisations that have a } \\
\text { vision, mission and slogans } \\
\text { indicating responsibility for } \\
\text { energy efficiency }\end{array}$ & 0.41 \\
\hline $\begin{array}{l}\text { Organisations that have a strategy in } \\
\text { place for energy consumption }\end{array}$ & $\begin{array}{l}\text { Internationally-owned } \\
\text { organisations }\end{array}$ & 0.39 \\
\hline $\begin{array}{l}\text { Energy efficiency will promote a } \\
\text { sustainable environment. }\end{array}$ & $\begin{array}{l}\text { Energy efficiency will help with } \\
\text { compliance with (future) } \\
\text { regulations or national } \\
\text { policies/strategies }\end{array}$ & 0.33 \\
\hline $\begin{array}{l}\text { Organisations that have a strategy in } \\
\text { place for energy consumption }\end{array}$ & $\begin{array}{l}\text { Overall success of the } \\
\text { organisation (it will be } \\
\text { important for survival) }\end{array}$ & 0.35 \\
\hline
\end{tabular}

Table 3: Other important correlations

There are strong correlations between the future expansion of the organisation and energy efficiency. A strongly positive correlation also exists between organisations that show that energy efficiency will influence their success, and organisations that include energy efficiency as a measurement of productivity. Organisations that have higher than expected annual growth are mostly those that also have procedures and policies in place for energy efficiency, offer more energy efficient products to their customers, and show more energy savings due to energy efficiency projects.

\subsection{Organisational issues relating to energy efficiency}

Organisations show that investment in projects that relate to the core business and in green energy projects is preferred, as longer paybacks are allowed for these projects. Most organisations, however, require energy efficiency projects to have a shorter payback. This is contrary to the World Business Council for Sustainable Development, which urged organisations to accept longer paybacks for projects related to energy efficiency and ecoefficiency. 
Most organisations use their in-house employees to design, implement, and measure and verify energy efficiency projects. The next choice is a combination of experts. Energy service companies are employed more to design, measure, and verify than to implement energy efficiency projects. Twelve percent of the organisations use international experts to design their energy efficient systems. This indicates that in some instances South Africa might not have the required expertise, leading organisations to use international experts.

Most of the organisations - around 70\% - have an energy consumption strategy in place. This indicates that energy efficiency is starting to play a role in the day-to-day operations of organisations. A very small percentage of organisations apply energy efficiency per product they produce, which shows that energy efficiency may not yet be included in the life cycle engineering of most products. Organisations regard the retrofitting of equipment, management tools, plant automation and control, and training on human intervention and behaviour as important ways to obtain better energy efficiency. Efficient water heating and green energy such as photovoltaic and wind generation are less important in obtaining energy efficiency or energy savings; $96 \%$ of the respondents showed that energy efficiency is more important to their organisations than green energy. This might be because the payback of green energy projects is typically longer than the payback of energy efficiency projects, due the relatively high acquisition costs of green energy technologies and the relatively low cost of energy at present. Most of the energy that is consumed by organisations is in the form of electricity, and this is also where organisations tend to concentrate when applying energy efficiency.

Organisational growth causes an associated growth in energy consumption. Energy efficiency has in most cases not averted the growth in energy consumption. Thus, on a year-to-year basis, organisations will still experience a growth in energy consumption from organisational growth. Fortunately, energy efficiency measures may offset the growth of energy consumption.

Government policies, regulations, and strategies for energy efficiency enforcement will encourage organisations to become more energy efficient. Only $6 \%$ of the respondents believed that these policies, regulations, and strategies will cause organisations to fail. This shows that the internal policies and strategies of organisations for energy efficiency projects are still in development, and governments could help to encourage organisations through their regulations, policies, and national strategies.

Most organisations already disclose their reduced energy consumption through energy efficiency to employees, stakeholders, and the public. Disclosure of this information is significant because it shows that organisations regard energy efficiency as an important aspect of their operations.

\section{CONCLUSIONS AND RECOMMENDATIONS}

Energy efficiency shows correlations with variables that contribute to organisational success. Some of these correlations might be due to successful organisations that apply energy efficiency from a financial perspective; but most of these successful organisations also invest into energy efficiency to be compliant with future regulations about energy efficiency and sustainable development. This shows that organisations regard energy efficiency as a method that contributes to their overall success

The studied sample size comprises only 34 organisations out of a total of 300 , which represents a confidence level of $83 \%$; but it included a wide variety of organisations from different locations, different sizes, and different industrial activity. Future studies of this kind should attempt to cover all such organisations in South Africa, and time should be given to obtaining a more significant sample size to determine, for example, the effect of organisational size, geographical location, and other factors. 


\section{REFERENCES}

[1] Tyteca, D., Carlens, J., Berkhout, F., Hertin, J., Wehrmeyer, W. \& Wagner, M. 2002. Corporate environmental evaluation: Evidence from the MEPI Project. University of Surrey, United Kingdom / University of Luebeburg, Germany.

[2] Galitsky, C., Price, L. \& Wottel, E. 2004. Energy efficiency programs and policies in the industrial sector in industrialized countries. Ernest Orlando Lawrence Berkeley National Laboratory, Orlando.

[3] Adams, C. \& Neely, A. 2002. Prism reform - Financial management. ABI/Inform Global.

[4] Painuly, J.P., Park, H., Lee, M.-K. \& Noh, J. 2002. Promoting energy efficiency financing and ESCOs in developing countries: Mechanisms and barriers. Department of Finance, Isenberg School of Management, South Korea.

[5] Hoerner, J. \& Mutl, J. 2002. Good business: A market analysis of energy efficiency policy. Centre for a Sustainable Economy, Washington DC, USA.

[6] Hutchinson, C. 1996. Integrating environment policy with business strategy. Elsevier Science Ltd, Great Britain.

[7] Neely, A., Adams, C. \& Kennerley, M. 2002. The performance prism: The scorecard of measuring and managing business success. Cranfield School of Management, USA.

[8] Page, C. \& Meyer, D. 2003. Applied research design for business and management. Australia.

[9] Gouws, P.A. 2010. The contribution of energy efficiency towards the success of industrial organisations in South Africa. Master's dissertation, Graduate School of Technology Management, University of Pretoria. 